\title{
Reconciling biodiversity conservation and agricultural expansion in the subarctic environment of Iceland
}

\author{
Lilja Jóhannesdóttir $^{1}, \underline{\text { José A. Alves }}^{1,2}$, Jennifer A. Gill $^{3}$ and Tómas G. Gunnarsson $^{1}$
}

\begin{abstract}
Intensified agricultural practices have driven biodiversity loss throughout the world, and although many actions aimed at halting and reversing these declines have been developed, their effectiveness depends greatly on the willingness of stakeholders to take part in conservation management. Knowledge of the willingness and capacity of landowners to engage with conservation can therefore be key to designing successful management strategies in agricultural land. In Iceland, agriculture is currently at a relatively low intensity but is very likely to expand in the near future. At the same time, Iceland supports internationally important breeding populations of many ground-nesting birds that could be seriously impacted by further expansion of agricultural activities. To understand the views of Icelandic farmers toward bird conservation, given the current potential for agricultural expansion, 62 farms across Iceland were visited and farmers were interviewed, using a structured questionnaire survey in which respondents indicated of a series of future actions. Most farmers intend to increase the area of cultivated land in the near future, and despite considering having rich birdlife on their land to be very important, most also report they are unlikely to specifically consider bird conservation in their management, even if financial compensation were available. However, as no agri-environment schemes are currently in place in Iceland, this concept is highly unfamiliar to Icelandic farmers. Nearly all respondents were unwilling, and thought it would be impossible, to delay harvest, but many were willing to consider sparing important patches of land and/or maintaining existing pools within fields (a key habitat feature for breeding waders). Farmers' views on the importance of having rich birdlife on their land and their willingness to participate in bird conservation provide a potential platform for the codesign of conservation management with landowners before further substantial changes in the extent of agriculture take place in this subarctic landscape.
\end{abstract}

Key Words: farmers; ground-nesting birds; Iceland; land use management; stakeholder perceptions; waders

\section{INTRODUCTION}

Combining commercially efficient agricultural land use with biodiversity conservation is one of the major challenges of modern times. Agricultural landscapes are complex socioecological systems, and achieving conservation objectives within these landscapes requires the integration of resource uses, landowner perspectives, and governance frameworks. As such, agricultural systems are similar to many other socioecological systems in which successful management or sustainable preservation of resources relies heavily on stakeholder involvement and suitable regulation that take complex feedback processes into account (Ostrom 2009). One key feature in successful conservation management is to consolidate the different interests of conservation and agriculture (Young et al. 2005, Redpath et al. 2013). This requires active communication to reconcile potential conflicts and ensure that different interests are appreciated from the outset, as well as having all parties involved working together toward mutually agreed goals (Redpath et al. 2013). Increases in agricultural extent and efficiency have driven widespread declines in biodiversity throughout the world (Donald et al. 2001, Foley et al. 2005, Millennium Ecosystem Assessment 2005), and as the human population increases, the demand for agricultural products will likely continue to grow. The increased demand for agricultural production has been met with both expansion of agricultural land and the intensification of land already used for agriculture, both of which have been shown to substantially impact biodiversity (Flowerdew 1997, Sotherton and Self 2000, Benton et al. 2003, Donald et al. 2006, Katayama et al. 2015). Different conservation approaches have been used to reduce the impact of agricultural expansion and intensification on farmland biodiversity. Two fundamentally different approaches have received a lot of attention: constrain the land area used for agriculture by maximizing its yield, even with high costs for local biodiversity, but sparing other areas for conservation, often referred to as "land sparing"; and maintain agricultural intensification at lower levels that may spread the impacts on biodiversity, often referred to as "land sharing" (Green et al. 2005). In either approach, the involvement of stakeholders is likely to be an important factor determining the success of conservation projects. Evidence suggests that farmers who participate in developing conservation schemes experience an increase in their commitment and satisfaction (Emery and Franks 2012). However, a fundamental step toward their early involvement is to understand their views on biodiversity conservation and their expectations of potential changes in future land management.

In areas where agriculture is restricted by environmental conditions, such as at high latitudes or altitudes, factors such as short growing seasons, extreme rainfall, or lack of soils can limit the opportunities for agricultural intensification. In these cases, increasing agricultural production usually requires expansion of agricultural land. At the subarctic latitude of Iceland $\left(63^{\circ}-66^{\circ}\right.$ North) the growing season is very short, which limits opportunities to intensify agricultural production, and increased demands for agricultural products are therefore likely to be met by expanding the area of cultivated land. However, the potential impact of such expansion on the species that occur in lowland Iceland is unknown. Icelandic biodiversity is characterized by relatively low species diversity but great abundance of many of

${ }^{1}$ University of Iceland, South Iceland Research Centre, ${ }^{2}$ DBIO, CESAM-Centre for Environmental and Marine Studies, University of Aveiro, Portugal, ${ }^{3}$ School of Biological Sciences, University of East Anglia, UK 
those species. Iceland supports internationally important breeding populations of 21 bird species (Einarsson et al. 2002) and hosts a large part of the world population for several bird species (Wetlands International 2006). Iceland is especially important for northern hemisphere breeding waders (Charadrii; Gunnarsson et al. 2006). It sustains very high densities of several species (Jóhannesdóttir et al. 2014) and is one of the most important breeding areas for waders in Europe (Thorup 2004). Iceland sustains such high densities in part because of large areas of open landscape with small-scale mosaics of suitable habitats that fulfil different breeding wader requirements (Gunnarsson et al. 2006, Pickett and Siriwardena 2011). This landscape has been shaped through the centuries by livestock grazing and deforestation, which, together with frequent volcanic activity (Arnalds 1987), have resulted in large areas of forest-free open landscapes. In the 20th century, extensive drainage projects were subsidized by the Icelandic government to increase agricultural opportunities and productivity. At that time $\sim 55 \%-75 \%$ of Icelandic wetlands were drained to some extent (Óskarsson 1998), which caused radical changes to habitats and landscape. For some breeding wader species, these changes might have initially been favorable, because some drainage may have increased the mosaic of available breeding habitats. Following the widespread drainage, the area of hayfields quadrupled in 30 years, slowing down in the 1980 s but maintaining an increasing trend (Snorrason et al. 2015). Currently, $6 \%$ of the area below 200 meters above sea level (m a. s.1.) is cultivated, but estimates suggest that $>60 \%$ of that area could potentially be converted to cultivated land (The Farmers Association of Iceland 2010, The Farmland Database 2013). This rate of conversion of seminatural habitats to farmland is alarming given the potential for both direct loss of breeding habitat for waders and degradation of the remaining habitat as a result of drainage of pools and advances in timing of harvest (Eglington et al. 2008).

The Icelandic government has recently placed more emphasis on limiting development (other than agriculture) on land that could be used for agriculture, (Alpingi 2015a), in anticipation of future increased demand for agriculture products driven by huge increases in tourism (the numbers of tourists visiting Iceland have increased by $185 \%$ since 2005 , going from 350,000 to 1 million; Óladóttir 2015), as well as growth in the Icelandic population, which is estimated to increase by $\sim 30 \%$ in the next 50 years (from 330,000 to 440,000 ; Statistics Iceland 2015a). Given projections for global increases in the human population (United Nations 2015 ), current forecasts predict a required $\sim 60 \%-110 \%$ increase in worldwide agricultural production (from levels in 2005) to meet the increased demand for produce (FAO 2009, Tilman et al. 2011).

Icelandic agriculture is limited by both geographical and geological factors. The oceanic climate results in prolonged periods with temperatures close to $0^{\circ} \mathrm{C}$ in winter and cool summers, with average temperatures being approximately $-1{ }^{\circ} \mathrm{C}$ in January and $10^{\circ} \mathrm{C}$ in July (Icelandic Meteorological Office 2015). The lowlands, where almost all agriculture occurs (generally defined as areas below 300-400 $\mathrm{m}$ a.s.1.), are characterized by a subarctic climate; while the highlands, covering much of the country, have low arctic to arctic conditions, with glacial icecaps covering about $10 \%$ of the country. Areas suitable for cultivation are mostly below $200 \mathrm{~m}$ a.s.1., which cover $\sim 15 \%$ of Iceland and where $\sim 90 \%$ of farms are located (National Land Survey of Iceland 2013). Annual rainfall ranges from 400 to $3000 \mathrm{~mm}$ (Icelandic Meteorological Office 2015), and the growing season is about 4 months. Volcanic activity is frequent in Iceland and causes severe erosion, leaving large areas vulnerable to soil degradation (Arnalds 2015). Agricultural production in Iceland is heavily subsidized (OECD 2015), accounting for $\sim 1 \%$ of annual GDP, and its production fulfils most dairy and meat demand in the domestic market (Jóhannesson 2010). Cultivated areas in Iceland are mostly hayfields that are both used for grazing and fodder production for livestock grown for meat and dairy production. The total area of hayfields at present is $\sim 120,000$ ha (The Farmers Association of Iceland 2010), with arable production being small-scale and mostly comprising barley grown for fodder on the farm where it is grown. Barley production is increasing, and barley is currently grown on $\sim 4000$ ha, yielding about $15,000-16,000$ tons and accounting for $10 \%-12 \%$ of the cereal used for livestock production (Tómasson et al. 2011). Icelandic agriculture consists of mostly three types of livestock: sheep, cattle, and horses. Sheep are kept indoors during winter and are grazed close to the farms in spring and autumn but during summer most are grazed in the highlands, so lowland farmland has few sheep during summer. Cattle are mostly kept indoors, but most dairy cows do roam in fields close to the farm during daytime in summer. Horses can stay outside the whole year and most do, though some are kept inside for riding and training purposes. Generally the density of livestock in Iceland is low. Livestock can impose a direct threat to breeding birds through trampling and predation of nests (Katrínardóttir et al. 2015), but grazing by livestock also helps to maintain the open landscape that provides conditions suitable for breeding (Durant et al. 2008).

The remaining areas of seminatural habitats in lowland Iceland currently sustain very high densities of breeding waders, particularly the remaining wetter habitats (e.g., marshes and bogs; (Jóhannesdóttir et al. 2014). The effect of the expansion of agriculture into areas of seminatural habitats could potentially be reduced by integrating conservation measures into land management, but currently there are very few restrictions on land management in Iceland (Alpingi 2015b). Given that almost all land in lowland Iceland where farming occurs is either privately owned or state property managed by farmers (Kristófersson et al. 2007), it is important to understand farmers' views and attitudes toward bird conservation on their land.

To explore the potential for collaboration with landowners, and which actions they would be willing to undertake for bird conservation, we visited farms across the main agricultural regions of lowland Iceland. We asked farmers a series of questions about their future land management and their attitudes toward birds and bird conservation, focusing on four specific conservation measures that are likely to be key in maintaining large breeding wader populations in farming regions (Table 1).

We also wanted to know whether Icelandic farmers might be more willing to consider participating in conservation management if financial compensation were available, much like the agrienvironment schemes that currently operate in many European countries (Kleijn and Sutherland 2003). Iceland is not a member of the EU but has considered joining in recent years. There are currently no conservation efforts aimed at breeding waders in 
Table 1. Details of the four agricultural land management issues likely to be of specific importance for breeding waders in lowland Iceland, and the mechanisms through which they can influence breeding wader distribution and demography.

\begin{tabular}{|c|c|c|}
\hline Conservation management & Impact on waders & References \\
\hline Grazing intensity & $\begin{array}{l}\text { Shapes vegetation height and heterogeneity; high levels of grazing create short, } \\
\text { homogeneous swards that can be unsuitable for foraging, sheltering, and } \\
\text { nesting } \\
\text { Livestock trampling of nests and chicks } \\
\text { Occasional egg and chick predation by livestock }\end{array}$ & $\begin{array}{l}\text { Vickery et al. 2001, Tichit et al. 2005, } \\
\text { Smart et al. 2006, Katrínardóttir et al. } \\
2015\end{array}$ \\
\hline Harvest timing & $\begin{array}{l}\text { Agricultural machinery can destroy clutches and chicks when timing of harvest } \\
\text { coincides with nesting and chick rearing } \\
\text { Can alter invertebrate food availability through changes in vegetation structure }\end{array}$ & $\begin{array}{l}\text { Schekkerman and Beintema 2007, Kleijn } \\
\text { et al. 2010, Schroeder et al. } 2012\end{array}$ \\
\hline Leaving pools intact & $\begin{array}{l}\text { Pools are an important source of invertebrate prey, and of water for drinking } \\
\text { and plumage maintenance }\end{array}$ & $\begin{array}{l}\text { Gunnarsson et al. 2005, Smart et al. } \\
\text { 2006, Eglington et al. } 2008\end{array}$ \\
\hline Sparing important areas & $\begin{array}{l}\text { Maintaining large areas that can provide the range of nesting locations, prey } \\
\text { resources, and places for chicks to hide from predators, at appropriate scales }\end{array}$ & $\begin{array}{l}\text { Whittingham 2007, Schekkerman et al. } \\
2008\end{array}$ \\
\hline
\end{tabular}

Iceland, despite the international importance of the large wader populations in Iceland; but Iceland's involvement in relevant international conservation agreements, such as the Ramsar Convention, the Bern Convention, and the African-Eurasian Waterbird Agreement (van Schmalensee et al. 2013), provides a potential platform for the development of appropriate conservation strategies. The concept of protecting wildlife is well established in Iceland, through protected areas and species protection legislation, but the there is no history of providing financial compensation to landowners for conservation actions.

\section{METHODS}

\section{Study location}

This study was undertaken in Iceland, an island in the NorthAtlantic Ocean located between $63^{\circ}$ and $66^{\circ}$ North on the mid Atlantic ridge. Agriculture in Iceland is still of relatively low intensity, and large patches of seminatural habitats, e.g., marshes, bogs, heaths, and river plains, are present in most agricultural areas. There has never been any biodiversity conservation action developed on agricultural land in Iceland.

Icelandic agriculture is primarily pastoral, and livestock number and composition vary regionally (Fig. 1a, b). Livestock in the South and North mostly comprise cattle and horses; the West has similar numbers of the three livestock species, while farms in East and in the West fjords have fewer horses and proportionally more sheep. Consequently, farms in three regions (South, West, and North; Fig. 1) were visited to explore any regional variation in views and attitudes.

\section{Questionnaire survey}

In the summers of 2013 and 2014, 62 farms (2.4\% of the total number of farms in Iceland; Statistics Iceland 2012) were visited (Fig. 1) and the farmers were questioned about their intentions regarding future farming practices and their views on bird conservation, the importance of birdlife, and their willingness to participate in different actions aimed at bird conservation. The farmers' age and gender and their farm characteristics (livestock number and composition) were recorded. For comparison livestock numbers were converted to livestock units (LUs) based upon the feed requirement of each livestock type: cattle $=0.9 \mathrm{LU}$ (with dairy cow $=1 \mathrm{LU}$ and cattle for meat production $=0.8$ ), horses $=0.8 \mathrm{LU}$, and sheep $=0.1 \mathrm{LU}($ Eurostat 2013). To measure farmers' views or plans, a 5-point Likert scale was used in which respondents were asked to assign a score that reflects the extent to which they agree or disagree with a series of statements $(1=$ very likely, $2=$ likely, $3=$ uncertain, $4=$ unlikely, $5=$ very unlikely and $1=$ strongly agree, $2=$ agree, $3=$ no opinion, $4=$ disagree, 5 = strongly disagree; Likert 1932). The Likert scale assumes the strength of experience is linear; on a continuum from strongly agree to strongly disagree, and that attitudes can be measured. This is vital to be able to quantify farmer's responses and views.

Fig. 1. Map of Iceland (top) showing areas below 400 meters above sea level in white and the surveyed farms (filled circles) in each of the regions (indicated by lines), and the regional variation in (a) total livestock units (LU: cattle $=0.9$; horses $=$ 0.8 ; sheep $=0.1$ ) and (b) composition of livestock units per farm (Statistics Iceland 2015b).

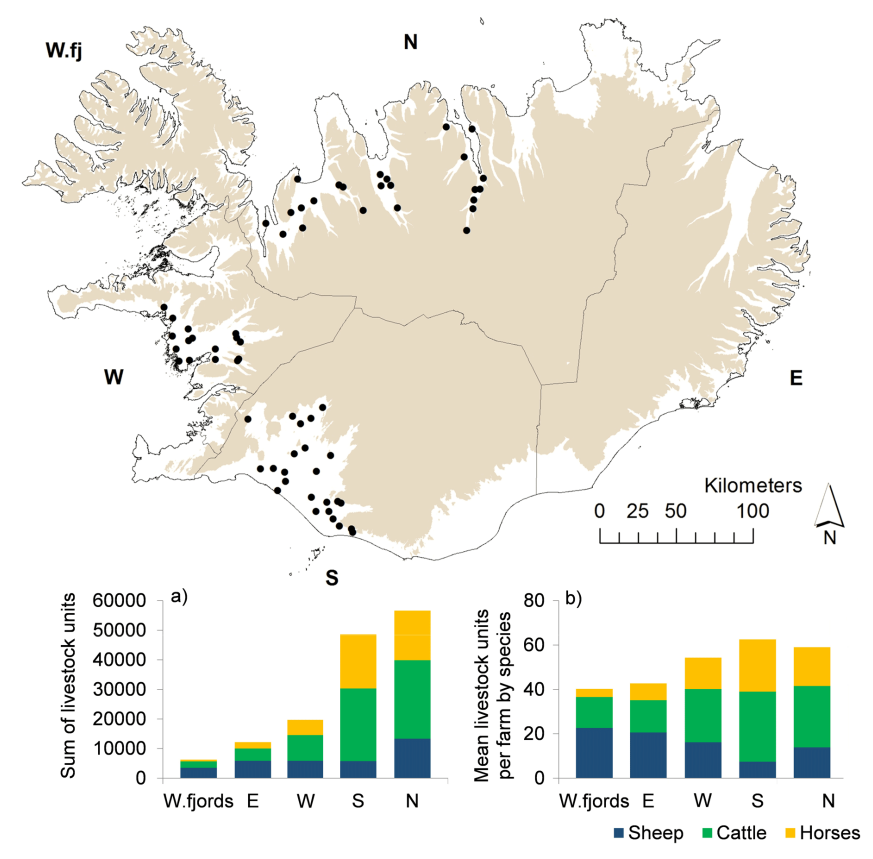


Farms were visited in three main agricultural regions (24 in the North and in the South and 16 in the West), which encompass the majority of agricultural production in Iceland (Fig. 1). Similar proportions of farms were surveyed in each region $(39 \%$ in the South, $26 \%$ in the West, and $35 \%$ in the North). Farms were selected visually from maps, ensuring similar numbers across the three regions, capturing geographical variation in farming practices, landscapes, and biodiversity, as well as the range of farm types regarding production capacity and livestock composition. To avoid spatial clustering, surveyed farms were selected to be $>5 \mathrm{~km}$ apart. However, in some areas recruiting farmers to participate in the study was difficult; often they were busy at the time of visiting and others did not want to participate. Consequently, on eight occasions farms were closer than the desired level (minimum distance $=2 \mathrm{~km})$.

\section{Data analysis}

Because views about biodiversity conservation may vary with age, respondents were classified as either younger (born after the median birth year of 1966, range: 1943-1990) or older (born before 1966; for interviewed couples the average age was used), and responses of these two groups to each question were compared with Fisher's exact tests. Similarly, response may vary regionally as a consequence of differences in land type, habitat, and landscape structure, and availability of land or livestock requirements; thus, regional differences were also compared with Fisher's exact tests.

Responses to questions regarding willingness to participate in conservation actions were classified as willing (very likely or likely) or unwilling (unlikely or very unlikely). The characteristics of respondents who were either willing or unwilling to both spare important land for birdlife and manage grazing for birdlife (the two relevant questions with sufficient variation in responses) were then compared with Mann-Whitney U tests, G-tests, or Fisher's exact tests, as appropriate. Statistical analyses were performed in the program IBM SPSS Statistics 22.0.

\section{RESULTS}

\section{Demographic characteristics of respondents}

The 62 farmers included in the surveys were all owners of the land they farm (all farms were family run), and the questionnaires were primarily completed by one member of the family, but in some cases ( 10 farms) by both members of a couple. Respondents varied in demographic characteristics; the oldest was born in 1943 and the youngest in 1990. Average year of birth was 1964 in the South ( \pm 13 years), 1960 in the West ( \pm 14 years), and 1971 in the North ( \pm 12 years). The majority were male $(69 \%)$, whereas $15 \%$ were female and $16 \%$ were couples (Fig. 2).

\section{Farm type}

Farms varied in numbers, type, and combination of livestock (Fig. 3a). Most farms in Iceland have a mixture of the three most common livestock: sheep, cattle, and horses. The vast majority of the farms in this study (93\%) had a mixture of two or three of these livestock types, and farms varied considerably in livestock numbers, ranging from 11 to 402 LUs (Fig. 3b).

\section{Prospects for future expansion of agriculture area}

More than half of the farmers $(63 \%)$ were likely or very likely to expand their agricultural area in the next five years, and this did not vary significantly across regions or between older and younger respondents (Fig. 4, question 1). Of the $20 \%$ of farmers that did not intend to increase their area of agricultural land, $8 \%$ have used all the suitable land they own for agriculture so they do not have the option to expand.

Fig. 2. Numbers of older and younger (than median birth year of 1966) farmers in each regions who answered questions as individuals (men or women) or as couples.

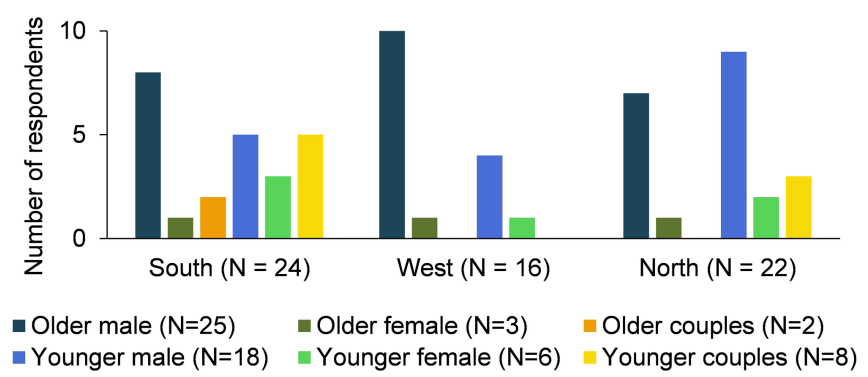

Fig. 3. Variation in (a) numbers and (b) livestock units of sheep, cattle, and horses on study farms in the three regions.

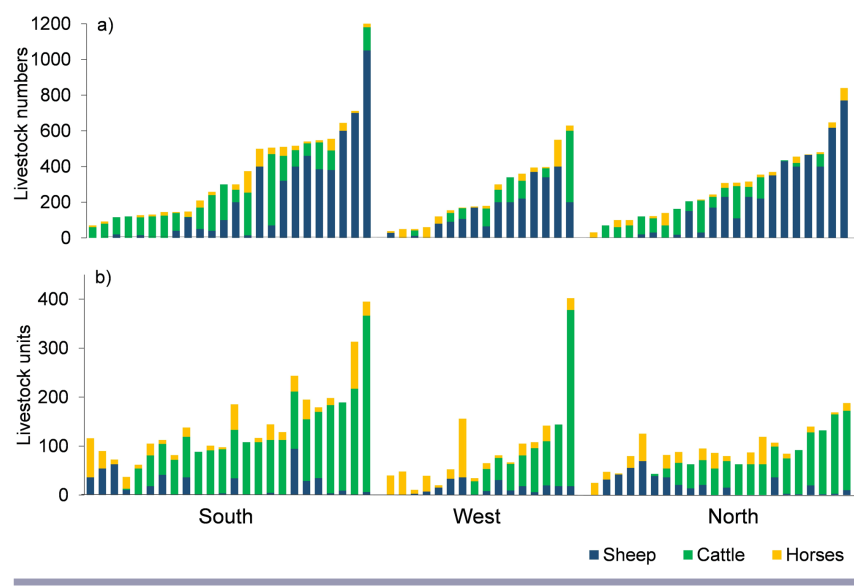

\section{Respondent views on birdlife and attitudes to managing for} birdlife

Nearly all farmers $(97 \%)$ agreed or strongly agreed that it is important to have rich birdlife on their estate, and older farmers were significantly more positive about this than younger farmers (Fig. 4, question 2; Fig. 5a). However, only $\sim 30 \%$ currently take birdlife into consideration when managing their land and this was not influenced by the concept of receiving financial incentives for these actions (Fig. 4, questions 3, 4). Again, significantly more older than younger farmers strongly agreed that they currently took birdlife into consideration (Fig. 4, Fig. 5b). The definition of "taking birdlife into consideration" was left open in order not to constrain farmers' ideas of what they thought would be beneficial to waders, but discussions with farmers about this issue focused around actions such as taking special care during mowing to protect nests and chicks and leaving wet features available. 
Fig. 4. The number of farmers responding to each question, their modal (most frequent) response (the mode number refers to the answers going from left to right: $1=$ very likely/strongly agree to $5=$ very unlikely/strongly disagree, and the percentage of respondents selecting each of the five possible responses), and the results of Fisher's exact tests of independence of differences in responses to each question between age groups (older or younger than median age) and regions (South, West, and North).

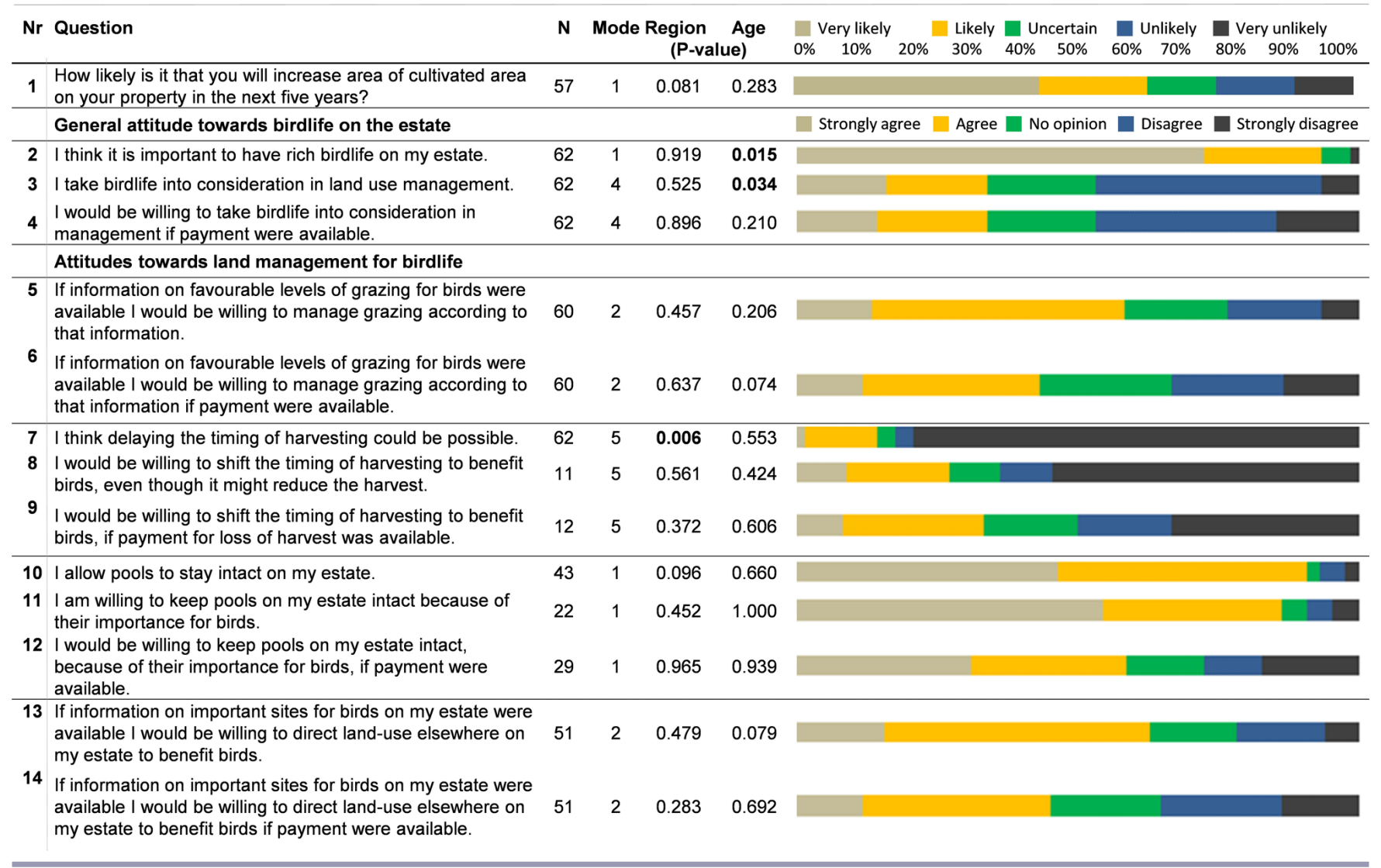

Fig. 5. Differences in responses between older and younger farmers to the statements (a) I think it is important to have rich birdlife on my estate and (b) I take birdlife into consideration in land use management, and between farmers in different regions to the statement (c) I think delaying the timing of harvesting could be possible (see Figure 4 for statistical analyses).

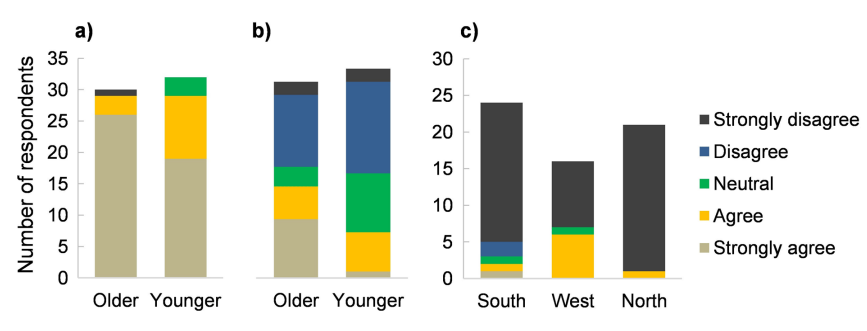

Responses regarding willingness to take part in different land management for birdlife varied depending on the proposed actions. More than 50\% indicated that they would be willing to manage grazing at a favorable level for birds (Fig. 4, question 5), around $90 \%$ either did not or would be willing not to drain pools on their estate (Fig. 4, questions 10, 11), and approximately $60 \%$ are willing to spare important patches for birds on their land (Fig.
4, question 13). However, delaying harvest of hayfields or arable land was an action most farmers did not undertake and would not consider undertaking, even if financial incentives were available (Fig. 4, questions 7-9). Only 9 farmers thought that such action would be possible and, of those, only 3 were willing to do so (Fig. 4, question 7). Farmers in the West were significantly more positive about delaying harvest (Fig. 4, Fig. 5c), although most still strongly disagreed that this was possible.

\section{Identifying farmers most likely or unlikely to participate in bird conservation}

The questions on whether farmers would be willing to manage their grazing and spare important sites for birdlife (Fig. 4, questions 5,13 ) had a range of responses and provided the opportunity to explore whether farmers with similar attitudes toward participating in bird conservation shared demographic characteristics. Farmers that responded as being likely or very likely to consider both actions were categorized as being willing (21 farmers) and farmers that were unlikely or very unlikely were categorized as unwilling (6 farmers, Fig. 6). Comparison of the two groups showed that they did not differ significantly in proportion of livestock and age, but they did differ between regions (Table 2), with a greater percentage of willing farmers both in the West (45\%) and the South (36\%) than in the North $(18 \%)$. 
Fig. 6. Identification of farmers who were willing (green circles) or unwilling (blue circles) to both manage grazing levels and spare important land to benefit birdlife. Grey circles indicate farmers who were either neutral or gave contrasting responses to these two questions. Points have been jittered to prevent overplotting.

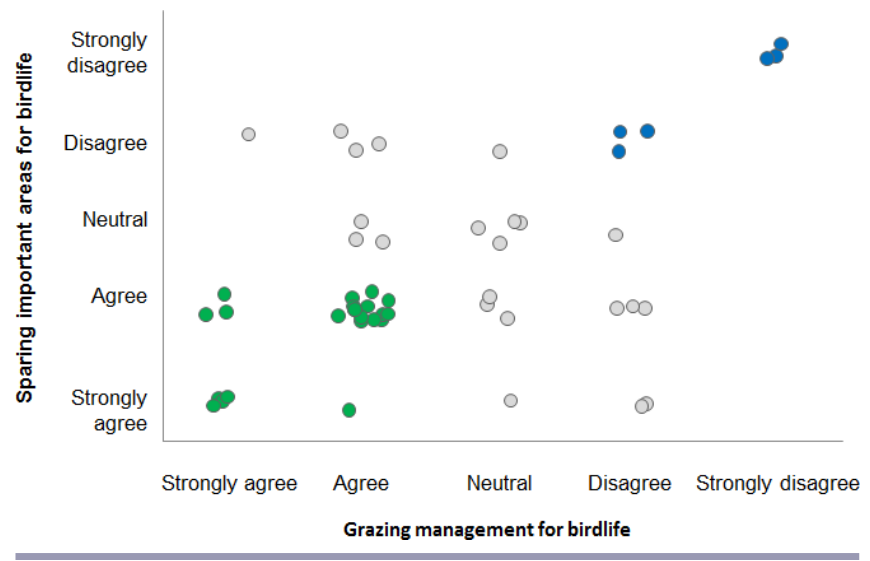

Table 2. Result of tests of the numbers of farmers that were either willing or unwilling to both manage grazing and spare important land to benefit birdlife in relation to their farm characteristics (Mann-Whitney tests), region (G-test), and age (older or younger than the median birth year of 1966, Fisher's exact test).

\begin{tabular}{|c|c|c|c|}
\hline Farm characteristics & & $\mathrm{U}_{226}$ & $\mathrm{p}$ \\
\hline Livestock units (LUs) & & 65 & 0.955 \\
\hline Sheep proportion & & 45 & 0.237 \\
\hline Cattle proportion & & 62 & 0.821 \\
\hline Horse proportion & & 47 & 0.287 \\
\hline Farmer characteristics & $\mathrm{G}$ & df & $\mathrm{p}$ \\
\hline Region & 6.182 & 2 & 0.045 \\
\hline Age & & 1 & 0.676 \\
\hline
\end{tabular}

\section{DISCUSSION}

The majority of the Icelandic farmers who took part in the survey plan to expand their agricultural land in the next five years, and this is likely to be driven further by increasing demands for farming products (Barkarson et al. 2014). This implies that conversion of seminatural land into farmland is likely to greatly increase in the near future, with potentially severe and widespread impacts on the internationally important bird populations that currently breed in these areas. Such expansion could put Iceland on a similar trajectory to many other countries that have experienced substantial biodiversity declines due to agricultural intensification and expansion (Millennium Ecosystem Assessment 2005). To maintain these globally important populations during agricultural expansion, it is important to know what conservation actions farmers may be willing and able to undertake (Young et al. 2005). Determining farmer attitudes toward having a rich birdlife on their land is an important first step in this process, because farmers that value birdlife may be more willing collaborators in the development of conservation management actions on their land. This is especially important because governance of land management is currently weak in Iceland and the socioeconomic system is unbalanced, with farmers having full control in the use of the remaining seminatural land resource (Ostrom 2009). This information could either be used to improve the governance or encourage farmers to take on self-governance to protect the resource.

\section{Farming for birds in Iceland}

The abundance of bird populations on agricultural land is typically a function of the intensity of agricultural operations (Schifferli 1999, Chamberlain et al. 2000, Donald et al. 2001, Murphy 2003). Agricultural processes such as the use of fertilizer, changes in landscape structure, and water level management can sometimes be beneficial at low intensities. Fertilizer-fueled increases in vegetation growth may provide more opportunities for chicks and adults to shelter from predators, and tall vegetation can support abundant invertebrate prey resources (Gunnarsson 2010, Jóhannesdóttir et al. 2014). Breeding waders often have a preference for mosaic landscapes (Milsom et al. 2002, Schekkerman et al. 2008, Oosterveld et al. 2011), which can be enhanced through agricultural processes, especially during the earlier stages of agricultural expansion, e.g., through drainage of wetlands creating drier areas that might be suitable for nesting, ditches providing open water resources, and hayfields providing abundant and accessible prey resources. However, increases in agricultural intensity typically result in rapid landscape homogenization, with the result that the resources required by breeding birds are no longer available at the appropriate scales. The negative impacts of agricultural intensification on birdlife are well described (Chamberlain et al. 2000, Donald et al. 2001, Donald and Evans 2006, Perlut et al. 2006), but the point at which landscapes begin to become unsuitable will likely depend on the system and species involved. The high densities of breeding waders in the lowland regions of Iceland (Jóhannesdóttir et al. 2014) in which agriculture is common may suggest that landscape structural complexity is still sufficient to provide the necessary resources. For that reason, it is understandable that Icelandic farmers might not perceive their farming practices as a particular threat to local biodiversity. However, given that farmers manage a large proportion of lowland areas in Iceland, where the vast majority of waders breed and where there are virtually no regulations on land use, their future actions have the potential to greatly impact wader populations.

\section{Farmers' views toward birds and their conservation}

The vast majority of the questioned farmers considered it important to have rich birdlife on their estate. This may be beneficial in developing and targeting successful conservation measures, because farmer attitudes are likely to reinforce their actions (Lynne et al. 1988, Vogel 1996). In Iceland, most farms are family owned, as was the case for all farms surveyed in this study, and many farmers had lived their entire life on the same farm. Such strong connections to the land can be beneficial for conservation, and can have a positive effect on the persons' concern for nature (Mayer and Frantz 2004). Although only onethird of the farmers reported that they currently take waders into consideration in their land management, they were generally 
positive toward participating in the four different conservation measures proposed. About $60 \%$ were likely or very likely to be willing to manage their grazing at levels favorable to waders if they were provided with appropriate instruction. The timing of farming operations, such as harvesting/mowing, can be crucial for breeding waders because they can result in the destruction of nests, chicks, and adults during the breeding season. For example, advances in timing of mowing of hayfields in the Netherlands has meant that this now coincides more frequently with wader nesting and chick rearing, causing unsuccessful breeding attempts and leading to lower recruitment (Kleijn et al. 2010). Because of the short growing season and changeable weather conditions in Iceland, particularly the relative lack of periods of dry weather that are required for hay processing, farmers have a short time window in which to mow their fields. Hence, few farmers $(<20 \%)$ think they have flexibility to change their timing of mowing, and the few who thought it would be possible reported they would be very unlikely to do it. A few farmers mentioned they might be willing to do this if they could be compensated with hay, but as the limitations on hay production (particularly the short growing season) are similar across Iceland, it is unlikely that the necessary excess hay production would be available. Delaying mowing is therefore a management action that is very unlikely to be achievable in Iceland at present.

High water levels and pools are very important for breeding waders as sources of invertebrate prey (Gunnarsson et al. 2005, Smart et al. 2006). It is therefore encouraging that about $90 \%$ of the farmer's reported that they already allow pools to stay intact on their property and that the great majority would be willing to spare them for birds. Maintaining pools is probably one of the most important management actions that farmers can undertake to support farmland biodiversity (Smart et al. 2006, Eglington et al. 2008). This is also linked to whether farmers would be willing to spare certain areas if they were known to be important to waders. Around $65 \%$ of farmers agreed or strongly agreed that their farming actions, e.g., natural land conversion, could be adapted to spare areas for birdlife, if they had appropriate support information to identify such areas. A focus on sparing wet areas would be an obvious first step, given the importance of water and wetlands for these species (Eglington et al. 2008, Jóhannesdóttir et al. 2014).

\section{Financial compensation}

In contrast to what was anticipated, the prospect of financial compensation did not increase the proportion of farmers who were willing to participate in the different conservation actions. Interestingly, some farmers reported that they were less likely to participate if they were to receive financial compensation, which probably reflects how unfamiliar this concept is to Icelandic farmers. Studies in the EU have shown that financial compensation is the most common reason for joining agrienvironment schemes (Wilson and Hart 2000), and Icelandic farmers did and do receive state subsidies for actions on their land, e.g., ditch construction for drainage and afforestation. However, there is no history of conservation measures in Icelandic farming, so both the concept of agri-environment schemes and compensation for participating in conservation efforts are novel to Icelandic farmers, many of whom had never previously considered the possibility of financial incentives for conservation management.

\section{Conservation implications}

Conservation action at these northern latitudes is likely to become necessary very soon, given the impending increase in the extent and intensity of agricultural activities. It is important to use experience from other countries to effectively integrate conservation actions with land use and management in farmed areas, and also to successfully cooperate with farmers and identify those most likely to be sufficiently engaged to allow long-term sustainable actions to be delivered. Although our questionnaire allowed identification of farmers who were consistently willing or unwilling to engage in conservation management actions, there was no clear link to any demographic group or farm type, other than farmers in the North were less willing to spare land or manage their grazing at favorable levels. However, this difference is probably caused by the fact that in the river valleys in the central North region, nearly all areas suitable for farming have been used, so farmers in the North have less flexibility in their management. This lack of demographic difference between the two groups of willing and unwilling farmers suggests that willingness to participate is an individual attribute, and studies such as ours are needed to identify willing participants. Older farmers did report more often that they found it important to have rich birdlife on their estate, but there was no evidence that they were more likely than younger farmers to participate in conservation management. Key steps in developing conservation management on Icelandic farmland will likely be raising awareness of the issues and providing farmers with sufficient time to process the available information, and thus to decide whether or not they wish to participate. This study will hopefully provide a platform for developing conservation actions for the globally important breeding wader populations in Iceland and potentially other subarctic environments. Planning and regulations for land management in these regions are rare, but rapid changes in land use are likely, given the changing climatic conditions and potential for global trade in agricultural products. However, as a signatory to international agreements on conservation of birds and wetlands (Ramsar Convention, Bern Convention and AfricanEurasian Waterbird Agreement), the Icelandic government is required to take action to protect the internationally important bird populations breeding in the country. Understanding what farmers believe is possible and would be willing to do, given their production aims, could help facilitate a more coordinated and collaborative approach to achieving these aims.

Responses to this article can be read online at: http://www.ecologyandsociety.org/issues/responses. $\mathrm{php} / 8956$

\section{Acknowledgments:}

We would like to thank the numerous farmers who were willing to participate in this research; without them this would not have been possible. For financial support we thank the Icelandic Research Fund (grant number 130412-051). 


\section{LITERATURE CITED}

Alpingi. 2015b. Lög um náttúruvernd. Ministry for the Environment and Natural Resources, Reykjavík, Iceland.

Alpingi. 2015a. Pingsályktun um Landsskipulagsstefnu 2015-2026. Ministry for the Environment and Natural Resources, Reykjavík, Iceland.

Arnalds, A. 1987. Ecosystem disturbance in Iceland. Arctic and Alpine Research 19:508-513. http://dx.doi.org/10.2307/1551417

Arnalds, Ó. 2015. The soils of Iceland. Springer, Dordrecht, The Netherlands. http://dx.doi.org/10.1007/978-94-017-9621-7

Barkarson, B. H., D. Kristjánsdóttir, E. Jónsson, N. Á. Lund, and S. F. Sigurðardóttir. 2014. Landnotkun i dreifbýli og sjálfbar landnýting-Áfangaskýrsla. Ministry for the Environment and Natural Resources, Reykjavík, Iceland.

Benton, T. G., J. A. Vickery, and J. D. Wilson, 2003. Farmland biodiversity: is habitat heterogeneity the key? Trends in Ecology \& Evolution 18:182-188. http://dx.doi.org/10.1016/S0169-5347 (03)00011-9

Chamberlain, D. E., R. J. Fuller, R. G. H. Bunce, J. C. Duckworth, and M. Shrubb. 2000. Changes in the abundance of farmland birds in relation to the timing of agricultural intensification in England and Wales. Journal of Applied Ecology 37:771-788. http:// dx.doi.org/10.1046/j.1365-2664.2000.00548.x

Donald, P. F., and A. D. Evans. 2006. Habitat connectivity and matrix restoration: the wider implications of agri-environment schemes. Journal of Applied Ecology 43:209-218. http://dx.doi. org/10.1111/j.1365-2664.2006.01146.x

Donald, P. F., R. E. Green, and M. F. Heath. 2001. Agricultural intensification and the collapse of Europe's farmland bird populations. Proceedings of the Royal Society of London Series B: Biological Sciences 268:25-29. http://dx.doi.org/10.1098/ rspb.2000.1325

Donald, P. F., F. J. Sanderson, I. J. Burfield, and F. P. J. van Bommel. 2006. Further evidence of continent-wide impacts of agricultural intensification on European farmland birds, 1990-2000. Agriculture, Ecosystems \& Environment 116:189-196. http://dx.doi.org/10.1016/j.agee.2006.02.007

Durant, D., M. Tichit, E. Kernéïs, and H. Fritz. 2008. Management of agricultural wet grasslands for breeding waders: integrating ecological and livestock system perspectives-a review. Biodiversity and Conservation 17:2275-2295. http://dx.doi. org/10.1007/s10531-007-9310-3

Eglington, S. M., J. A. Gill, M. Bolton, M. A. Smart, W. J. Sutherland, and A. R. Watkinson. 2008. Restoration of wet features for breeding waders on lowland grassland. Journal of Applied Ecology 45:305-314. http://dx.doi.org/10.1111/ j.1365-2664.2007.01405.x

Einarsson, Ó., H. Kristinsson, K. H. Skarphéðinsson, and J. G. Ottósson. 2002. Verndun tegunda og svaða: tillögur Náttúrufraðistofnunar Íslands vegna Náttúruverndarácetlunar. The Icelandic Institute of Natural History, Reykjavík, Iceland.

Emery, S. B., and J. R. Franks. 2012. The potential for collaborative agri-environment schemes in England: can a well- designed collaborative approach address farmers' concerns with current schemes? Journal of Rural Studies 28:218-231. http://dx. doi.org/10.1016/j.jrurstud.2012.02.004

Eurostat. 2013. Glossary: Livestock unit (LU). Eurostat, Luxembourg. [online] URL: http://ec.europa.eu/eurostat/ statistics-explained/index.php/Glossary:Livestock unit (LSU).

Food and Agricultural Organization of the United Nations (FAO). 2009. How to feed the world in 2050. Proceedings of the Expert Meeting on How to Feed the World in 2050. FAO, Rome, Italy.

Flowerdew, J. 1997. Mammal biodiversity in agricultural habitats Pages 25-40 in R. C. Kirkwood, editor. Biodiversity and conservation in agriculture. BCPC Publications, Brighton, UK.

Foley, J. A., R. DeFries, G. P. Asner, C. Barford, G. Bonan, S. R. Carpenter, F. S. Chapin, M. T. Coe, G. C. Daily, H. K. Gibbs, J. H. Helkowski, T. Holloway, E. A. Howard, C. J. Kucharik, C. Monfreda, J. A. Patz, I. C. Prentice, N. Ramankutty, and P. K. Snyder. 2005. Global consequences of land use. Science 309:570-574. http://dx.doi.org/10.1126/science.1111772

Green, R. E., S. J. Cornell, J. P. W. Scharlemann, and A. Balmford. 2005. Farming and the fate of wild nature. Science 307:550-555. http://dx.doi.org/10.1126/science.1106049

Gunnarsson, T. G. 2010. Votlendi og vaðfuglar í ljósi landnotkunar. Náttúrufræðingurinn 79:75-86.

Gunnarsson, T. G., J. A. Gill, G. F. Appleton, H. Gíslason, A. Garðarsson, A. R. Watkinson, and W. J. Sutherland. 2006. Largescale habitat associations of birds in lowland Iceland: implications for conservation. Biological Conservation 128:265-275. http://dx.doi.org/10.1016/j.biocon.2005.09.034

Gunnarsson, T. G., J. A. Gill, Æ. Petersen, G. F. Appleton, and W. J. Sutherland. 2005. A double buffer effect in a migratory shorebird population. Journal of Animal Ecology 74:965-971. http://dx.doi.org/10.1111/j.1365-2656.2005.00994.x

Icelandic Meteorological Office. 2015. Veðurfar á Íslandi. Icelandic Meteorological Office, Reykjavík, Iceland. [online] URL: http://www.vedur.is/vedur/vedurfar/manadayfirlit/

Jóhannesdóttir, L., Ó. Arnalds, S. Brink, and T. G. Gunnarsson. 2014. Identifying important bird habitats in a sub-arctic area undergoing rapid land-use change. Bird Study 61:544-552. http:// dx.doi.org/10.1080/00063657.2014.962481

Jóhannesson, T. 2010. Pages 1-32 in Agriculture in Iceland: conditions and characteristics. Agricultural University of Iceland, Reykjavík, Iceland.

Katayama, N., T. Osawa, T. Amano, and Y. Kusumoto. 2015. Are both agricultural intensification and farmland abandonment threats to biodiversity? A test with bird communities in paddydominated landscapes. Agriculture, Ecosystems \& Environment 214:21-30. http://dx.doi.org/10.1016/j.agee.2015.08.014

Katrínardóttir, B., J. A. Alves, H. Sigurjónsdóttir, P. Hersteinsson, and T. G. Gunnarsson. 2015. The effects of habitat type and volcanic eruptions on the breeding demography of Icelandic Whimbrels Numenius phaeopus. PloS One 10:e0131395. http://dx. doi.org/10.1371/journal.pone.0131395 
Kleijn, D., H. Schekkerman, W. J. Dimmers, R. J. M. Van Kats, D. Melman, and W. A. Teunissen. 2010. Adverse effects of agricultural intensification and climate change on breeding habitat quality of Black-tailed Godwits Limosa l. limosa in the Netherlands. Ibis 152:475-486. http://dx.doi.org/10.1111/ j.1474-919X.2010.01025.X

Kleijn, D., and W. J. Sutherland. 2003. How effective are European agri-environment schemes in conserving and promoting biodiversity? Journal of Applied Ecology 40:947-969. http://dx. doi.org/10.1111/j.1365-2664.2003.00868.x

Kristófersson, D. M., E. Bjarnadóttir, and Ó. S. Jónsson. 2007. Eignarhald á jörðum, framleiðsla og próun hennar. Freyr 103.

Likert, R. 1932. A technique for the measurement of attitudes. Archives of Psychology 22(140):55.

Lynne, G. D., J. S. Shonkwiler, and L. R. Rola. 1988. Attitudes and farmer conservation behavior. American Journal of Agricultural Economics 70:12-19. http://dx.doi.org/10.2307/1241971

Mayer, F. S., and C. M. Frantz. 2004. The connectedness to nature scale: a measure of individuals' feeling in community with nature. Journal of Environmental Psychology 24:503-515. http://dx.doi. org/10.1016/j.jenvp.2004.10.001

Millennium Ecosystem Assessment. 2005. Ecosystems and human well-being: synthesis. Island Press, Washington, D.C., USA.

Milsom, T. P., J. D. Hart, W. K. Parkin, and S. Peel. 2002. Management of coastal grazing marshes for breeding waders: the importance of surface topography and wetness. Biological Conservation 103:199-207. http://dx.doi.org/10.1016/S0006-3207 (01)00122-7

Murphy, M. T. 2003. Avian population trends within the evolving agricultural landscape of eastern and central United States. Auk 120:20-34. http://dx.doi.org/10.1642/0004-8038(2003)120[0020: APTWTE]2.0.CO;2

National Land Survey of Iceland. 2013. Icelandic statistics. National Land Survey of Iceland, Arkanes, Iceland. [online] URL: http://www.lmi.is/wp-content/uploads/2014/07/island_i_tolum. pdf

Óladóttir, O. 2015. Tourism in Iceland in figures. Icelandic Tourist Board, Reykjavík, Iceland.

Oosterveld, E. B., F. Nijland, C. J. M. Musters, and G. R. de Snoo. 2011. Effectiveness of spatial mosaic management for grassland breeding shorebirds. Journal of Ornithology 152:161-170. http:// dx.doi.org/10.1007/s10336-010-0561-5

Organisation for Economic Co-operation and Development (OECD). 2015. Agricultural policy monitoring and evaluation. OECD Publishing, Paris, France.

Ostrom, E. 2009. A general framework for analyzing sustainability of social-ecological systems. Science 325:419-422. http://dx.doi.org/10.1126/science.1172133

Óskarsson, H. 1998. Framræsla votlendis á Vesturlandi. Pages 121-129 in J. S. Ólafsson, editor. Íslensk votlendi-verndun og nýting. University of Iceland Press, Reykjavík, Iceland.
Perlut, N. G., A. M. Strong, T. M. Donovan, and N. J. Buckley. 2006. Grassland songbirds in a dynamic management landscape: behavioral responses and management strategies. Ecological Applications 16:2235-2247. http://dx.doi.org/10.1890/1051-0761 (2006)016[2235:GSIADM]2.0.CO:2

Pickett, S. R. A., and G. M. Siriwardena. 2011. The relationship between multi-scale habitat heterogeneity and farmland bird abundance. Ecography 34:955-969. http://dx.doi.org/10.1111/ j.1600-0587.2011.06608.x

Redpath, S. M., J. Young, A. Evely, W. M. Adams, W. J. Sutherland, A. Whitehouse, A. Amar, R. A. Lambert, J. D. C. Linnell, A. Watt, and R. J. Gutiérrez. 2013. Understanding and managing conservation conflicts. Trends in Ecology \& Evolution 28:100-109. http://dx.doi.org/10.1016/j.tree.2012.08.021

Schekkerman, H., and A. J. Beintema. 2007. Abundance of invertebrates and foraging success of Black-tailed Godwit Limosa limosa chicks in relation to agricultural grassland management. Ardea 95:39-54. https://doi.org/10.5253/078.095.0105

Schekkerman, H., W. Teunissen, and E. Oosterveld. 2008. The effect of 'mosaic management' on the demography of black-tailed godwit Limosa limosa on farmland. Journal of Applied Ecology 45:1067-1075.

Schifferli, L. 1999. Changes in agriculture and the status of birds breeding in European farmland. Pages 17-25 in Ecology and conservation of lowland farmland birds. British Ornithologists' Union, Southampton, UK.

Schroeder, J., T. Piersma, N. M. Groen, J. Hooijmeijer, R. Kentie, P. M. Lourenco, H. Schekkerman, and C. Both. 2012. Reproductive timing and investment in relation to spring warming and advancing agricultural schedules. Journal of Ornithology 153:327-336. https://doi.org/10.1007/s10336-011-0747-5

Smart, J., J. A. Gill, W. J. Sutherland, and A. R. Watkinson. 2006. Grassland-breeding waders: identifying key habitat requirements for management. Journal of Applied Ecology 43:454-463. http:// dx.doi.org/10.1111/j.1365-2664.2006.01166.x

Snorrason, A., J. Pórsson, J. Guðmundsson, K. Andrésson, P. V. K. Jónsson, S. Einarsson, and V. Ú. Hellsing. 2015. National inventory report 2015: emissions of greenhouse gases in Iceland from 1990 to 2010: submitted under the United Nations Framework convention on climate change and Kyoto Protocol. Environment Agency of Iceland, Reykjavík, Iceland.

Sotherton, N. W., and M. J. Self. 2000. Changes in plant and arthropods biodiversity on lowland farmland: an overview. Pages 26-35 in Ecology and conservation of lowland farmland birds. British Ornithologists' Union, Southampton, UK.

Statistics Iceland. 2012. Statistical series: fisheries and agriculture. Statistics Iceland, Reykjavík, Iceland.

Statistics Iceland. 2015b. Búpeningur eftir landsvæðum frá 1998. Statistics Iceland, Reykjavík, Iceland. [online] URL: http://px. hagstofa.is/pxis/pxweb/is/Atvinnuvegir/Atvinnuvegir landbunadur landbufe/LAN10102.px/table/tableViewLayout1/?rxid=d252146bdbae-4a14-a7b5-01d1f57b7134.

Statistics Iceland. 2015a. Mannfjöldaspá 2015-2065. Statistics Iceland, Reykjavík, Iceland. 
The Farmers Association of Iceland. 2010. Hagtölur landbúnaðarins. The Farmers Association of Iceland, Reykjavík, Iceland.

The Farmland Database. 2013. The farmland database. [online] URL: http://www.nytjaland.is

Thorup, O. 2004. Breeding waders in Europe 2000. International Wader Studies. Wader Study Group, Thetford, UK.

Tichit, M., D. Durant, and E. Kerneis. 2005. The role of grazing in creating suitable sward structures for breeding waders in agricultural landscapes. Livestock Production Science 96:119-128. https://doi.org/10.1016/j.livprodsci.2005.05.010

Tilman, D., C. Balzer, J. Hill, and B. L. Befort. 2011. Global food demand and the sustainable intensification of agriculture. Proceedings of the National Academy of Sciences of the United States of America 108:20260-20264. http://dx.doi.org/10.1073/ pnas. 1116437108

Tómasson, T., Á. Helgadóttir, B. Thorkelsdóttir, E. Sigurðsson, H. Harðarsson, J. Hermannsson, Ó. Eggertsson, and S. Ingvarsson. 2011. Tillögur starfshóps um eflingu kornrcektar á Íslandi. Ministry of Fisheries and Agriculture, Reykjavík, Iceland.

United Nations. 2015. World population prospects: the 2015 revision, key findings and advance tables. Department of Economic and Social Affairs, Population Division, United Nations, New York, USA. http://dx.doi.org/10.18356/08b807d4-en

van Schmalensee, M., K. H. Skarphéðinsson, H. Vésteinsdóttir, T. G. Gunnarsson, P. Hersteinsson, A. L. Arnpórsdóttir, H. Arnardóttir, and S. B. Hauksson. 2013. Vernd, velferð og veiðar villtra fugla og spendýra. Ministry for the Environment and Natural Resources, Reykjavík, Iceland.

Vickery, J. A., J. R. Tallowin, R. E. Feber, E. J. Asteraki, P. W. Atkinson, R. J. Fuller, and V. K. Brown. 2001. The management of lowland neutral grasslands in Britain: effects of agricultural practices on birds and their food resources. Journal of Applied Ecology 38:647-664. https://doi.org/10.1046/j.1365-2664.2001.00626. $\underline{\mathrm{x}}$

Vogel, S. 1996. Farmers' environmental attitudes and behavior: a case study for Austria. Environment and Behavior 28:591-613. http://dx.doi.org/10.1177/001391659602800502

Wetlands International. 2006. Waterbird population estimates. Wetlands International, Wageningen, The Netherlands.

Whittingham, M. J. 2007. Will agri-environment schemes deliver substantial biodiversity gain, and if not why not? Journal of Applied Ecology 44:1-5. https://doi.org/10.1111/j.1365-2664.2006.01263. $\underline{\mathrm{x}}$

Wilson, G. A., and K. Hart. 2000. Financial imperative or conservation concern? EU farmers' motivations for participation in voluntary agri-environmental schemes. Environment and Planning A 32:2161-2186. http://dx.doi.org/10.1068/a3311

Young, J., A. Watt, P. Nowicki, D. Alard, J. Clitherow, K. Henle, R. Johnson, E. Laczko, D. McCracken, S. Matouch, J. Niemela, and C. Richards. 2005. Towards sustainable land use: identifying and managing the conflicts between human activities and biodiversity conservation in Europe. Biodiversity \& Conservation 14:1641-1661. http://dx.doi.org/10.1007/s10531-004-0536-Z 